\title{
Is there a nexus between China outward foreign direct investment and welfare in Côte d'Ivoire? Empirical evidence from the Toda-Yamamoto procedure
}

\author{
Ehouma Jacques Allou' (i) | Bosede Ngozi Adeleye ${ }^{2,3,4}$ (c) | Jianhua Cheng ${ }^{1}$ | \\ Rehman Abdul ${ }^{5}$ (1)
}

${ }^{1}$ School of Economics, Anhui University, Hefei, China

${ }^{2}$ Department of Economics and Development Studies, Covenant University, Ota, Nigeria

${ }^{3}$ Regional Centre of Expertise (RCE), Ogun State, Nigeria

${ }^{4}$ Centre for Economic Policy and Development Research (CEPDeR), Covenant University, Ota, Nigeria

${ }^{5}$ College of Economics and Management, Henan Agricultural University,

Zhengzhou, China

Correspondence

Allou Ehouma Jacques, School of

Economics, Anhui University, Hefei 230039, China.

Email: ehoumanallou14@gmail.com

\begin{abstract}
Foreign direct investment (FDI) plays an important role in the socio-economic advancement of developing countries. In the last decade, FDI inflows from China into Côte d'Ivoire have grown rapidly. Using quarterly time series data from 2003Q1 to 2017Q4, this study probes if China FDI has any significant welfare impact on the citizens of Côte d'Ivoire vis-à-vis if a causal relationship exists. The policy outcome is to stimulate further discourse that will reduce poverty and enhance the living standard of the population. The study uses vector autoregressive (VAR) and the Toda and Yamamoto (1995) modification of the non-Granger causality test to determine if a causal relationship exists and the direction of causality. The empirical analysis provides evidence of a unidirectional causality from China FDI to social welfare (proxied by the human development index [HDI]) but no indication of causality between China FDI to economic welfare (proxied by real gross domestic product per capita [GDPPC]). This study, which is borne out of empirical curiosity, fills a lacuna in the FDI literature. To the best of our knowledge, this paper is a novel contribution that examines the FDI-welfare nexus between China and a developing economy like Côte d'Ivoire. Thus, policies that will further stimulate FDI inflows from China must be carefully crafted to attract funding to the most productive sectors of the economy in order to improve both social and economic welfare. By extension, the policies may be adapted by developing economies with similar characteristics to Côte d'Ivoire.
\end{abstract}

\section{1 | INTRODUCTION}

The "One Belt and One Road" initiative of the Chinese government allows Chinese firms to invest in Africa with a view to promoting a "win-win and multi-win cooperation" in host countries in the form of foreign direct investment (FDI). This ingenuity made Africa one of the main economic and commercial partners of China in the Sino-Afro cooperation (Yanxia \& Meibo, 2015). For a successful implementation, the Chinese governmentthrough the Forum on China-Africa Cooperation (FOCAC)-implemented strategies to help African countries 
accelerate economic development and eradicate the menace of poverty. In particular, the intensification of FDI from China to sub-Saharan Africa (SSA) has resulted in high gross domestic product (GDP) growth (Doku, Akuma, \& Owusu-Afriyie, 2017) and the attendant welfare effects have become a major discourse in economic and socio-political debates between Chinese and African diplomatic relations in the last two decades. That is, to what extent have Sino-Afro investments affected welfare outcomes in Africa? Ironically, despite the high influx of FDI and growth rates, SSA remains the region most affected by the phenomenon of poverty and inequality (Adeleye, Osabuohien, \& Bowale, 2017). According to a World Bank (2018) report, the number of people living in extreme poverty increased in the region from 278 million in 1990 to 413 million in 2015. This can be attributed to multiple conflicts, fragility of institutions, and the inability to capitalize on growth to reducing poverty. Hence, poverty alleviation goals and improving economic welfare are integrated into the 2030 sustainable development goals (SDGs) due to the concern of the international community (Yanxia \& Meibo, 2015).

The scope on Côte d'Ivoire is important and worthy of an empirical investigation for several reasons. Besides the fact that it is the second largest economy in West Africa (Gamassa \& Chen, 2017), the francophone country is ravaged by a decade of conflicts and political instability in the $2000 \mathrm{~s}$, which worsened economic potentials and increased the poverty rate of its citizenry. To revive the economy, the country signed economic pacts with several countries including China. According to the Xinhua News Agency (2018), since the establishment of diplomatic relations with China on 2 March 1983, both countries have witnessed increased and extensive economic cooperation (Aurégan, 2017). Substantively, China is one of Côte d'Ivoire's main trading partners with net FDI increasing exponentially from US\$0.62 million in 2003 to about US\$112.2 million in 2017 (Mofcom, 2015). Similarly, the country's growth rate of GDP recorded in 2016 was the second fastest in SSA (World Bank, 2017) and in relation to social welfare, the country's human development index (HDI) which measures the quality of life, improved in the last decades (UNDP, 2018). According to a United Nations Development Programme report (UNDP, 2016), HDI classification is as follows: low < 0.550 ; medium $=0.550$ to 0.699 ; high $=0.700$ to 0.799 , very high $>0.800$. The index of Côte d'Ivoire increased from 0.4 in 2003 to 0.492 in 2017, though the country is still considered as having a low index given the classification thresholds. As a result, China FDI presents itself as an instrument of economic growth and thus improves the general welfare of the population by providing employment opportunities, facilitating technology and management benefits, as well as economic opportunities (Ross, 2015). Therefore, the question of whether these FDI inflows from China have significant welfare effects on the citizens of Côte d'Ivoire gives justification for this research.

Many studies (Belloumi, 2014; Doku et al., 2017; Megbowon, Mlambo, \& Adekunle, 2019) have been conducted on the FDI-growth nexus in Africa, but its relationship with welfare has been sparsely considered. Hence, our main contributions to the FDI literature and study objectives are to determine the impact of China FDI on welfare outcomes in Côte d'Ivoire and establish if causal relations exist. To achieve these, two key questions are framed: (a) is the improvement of HDI and GDP per capita in Côte d'Ivoire attributable to the increase in China FDI? (b) Does a causal relation exists between China FDI and HDI on the one hand and China FDI and per capita income in Côte d'Ivoire? In the attempt to answer these questions, three variables are used: FDI inflows from China, HDI (proxy for social welfare), and GDP per capita (proxy for economic welfare) and the empirical techniques employed are: the vector autoregressive (VAR) mechanism and the Toda-Yamamoto non-Granger causality test. Some of the findings support the hypotheses that welfare improvement in Côte d'Ivoire is partly attributable to the increase in China FDI. The rest of the paper is structured as follows: Section 2 details the synopsis of China FDI in Côte d'Ivoire; Section 3 reviews the theoretical and empirical literature; Section 4 outlines the data and empirical methodology; Section 5 discusses the results; while Section 6 concludes with policy recommendations.

\section{I SYNOPSIS OF CHINA OUTWARD FDI IN CÔTE D'IVOIRE}

Figure 1 shows the evolution of China FDI in Côte d'Ivoire from 2003Q1 to 2017Q4. The graphical analysis reveals two major periods of growth. The first period from 2003Q1 to 2013Q4 is marked by socio-political instability with the 2002 civil war and the post-electoral crisis in 2010. Indeed, in 2003Q1, the negative value of China FDI flows stood at US\$2.58 million which later increased from 2003Q3 to 2005Q1. The value dropped and reached negative values respectively in 2006, 2008, and 2010. Moreover, over the period, an average of US\$0.372 million was recorded. 


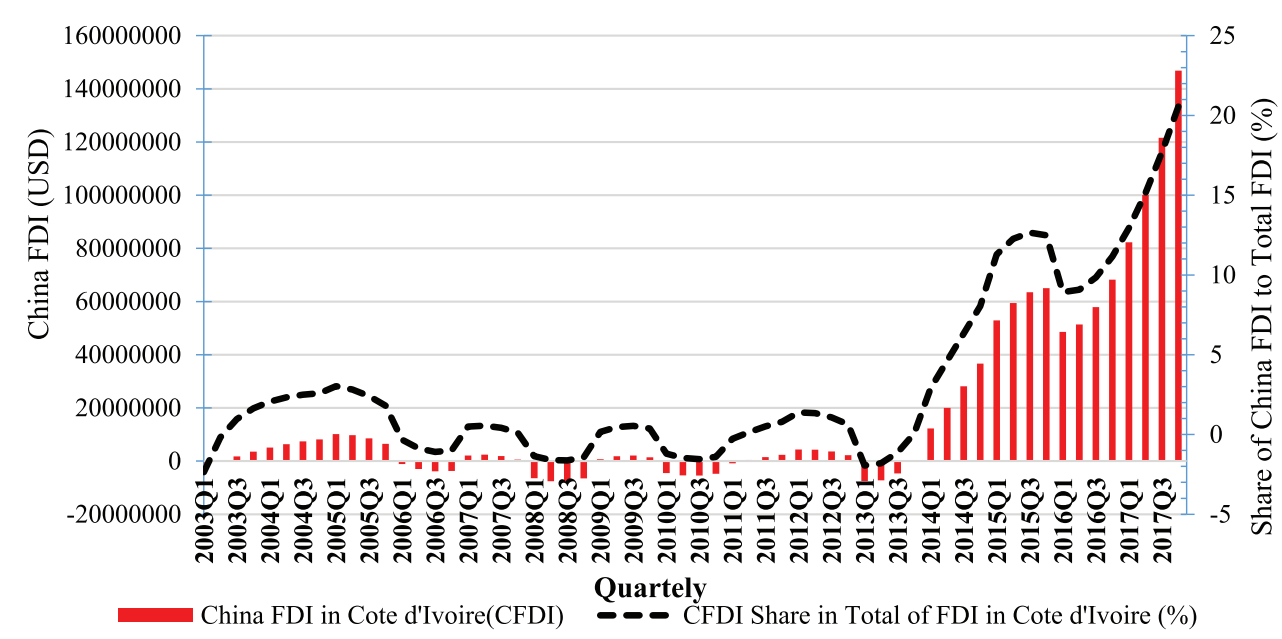

FI G URE 1 Evolution of China FDI in Côte d'Ivoire. Source: Authors' computations [Color figure can be viewed at wileyonlinelibrary.com]

The second period from 2014Q1 to 2017Q4 marked the re-establishment of political stability following the presidential elections in 2015. Having gained appreciable trust within the polity, total FDI inflows increased significantly from US\$12.283 million in 2014Q1 to US\$146.846 million in 2017Q, which coincidentally is the largest value recorded.

However, as shown in Table 1, despite significant increase in FDI the analysis of China's shares in total FDI inflows to Côte d'Ivoire brings a much more disappointing picture of the performance of Côte d'Ivoire to attracting of China FDI. This outlook suggests a huge marginalization of Côte d'Ivoire as a recipient of China FDI. In fact, FDI inflows from China to total inward FDI shows that China's share to total FDI inflows is quite marginal. For instance, China's share in FDI inflows to Côte d'Ivoire averaged only $4.27 \%$ over the period 2003Q1-2017Q4, compared to a very low value of $-0.26 \%$ over the period 2009Q1-2011Q4. Perceived marginalization of Côte d'Ivoire from China FDI is also visible on a per capita basis. As observed from the data, China FDI constitutes a smaller proportion of funds flowing to Côte d'Ivoire in the period 2003Q1-2013Q4. This is because China is a new entrant in the Ivorian market and Chinese investors have been reluctant due to the country's unstable political climate (Seka \& Kouakou, 2008). In addition, China FDI as a share of GDP over the study period is rather small, amounting to less than 1\% of GDP, and often negative over the period 2006 to 2008 and 2011 to 2013.

The exceptional increase of China FDI into Côte d'Ivoire is partly attributable to the introduction of various reforms such as improving the business climate via the implementation of a dedicated Commercial Court for business rulings, incentives to private investors, improving governance and transparency of public institutions with public financial management. Table 2 provides information on the destinations of China Official Development Assistance (ODA) in different business sectors in Côte d'Ivoire from 1983 to 2013. These ODAs include donations, "solidarity" loans and concessional loans, China public agreements and investments, partnerships, and/or conventions.

In 2013, China ODA in Côte d'Ivoire increased by nearly US $\$ 10,983.02$ million. From 30 years of economic cooperation, a total of 112 from 174 projects covering 11 domains have been funded. These investments are largely concentrated in infrastructure with a total of 28 projects of which 20 are funded at the cost of about US\$9055.40 million, closely followed by the telecommunications sector with six projects with five funded at an estimated cost of US $\$ 835,54543$ million. Given that most China ODAs in Côte d'Ivoire are focused on infrastructures, other funded domains are agriculture, education, and trade-economic with 12,4 , and 48 funded projects, respectively.

TABLE 1 China FDI inflows to total FDI inflows, 2003Q1 to 2017Q4

\begin{tabular}{|lllllll} 
& 2003Q1-2005Q4 & 2006Q1-2008Q4 & 2009Q1-2011Q4 & 2012Q1-2014Q4 & 2015Q1-2017Q4 & Total \\
\hline China FDI (a) & 64.44 & -32.76 & -10.56 & 92.32 & 917.84 & 1031.8 \\
\hline Total FDI (b) & $31,88.99$ & $5,041.43$ & $4,222.91$ & $4,706.09$ & $6,985.49$ \\
\hline \% share of (a) to (b) & 2.02 & -0.65 & -0.25 & 1.96 & 13.14 & $24,144.92$ \\
\hline
\end{tabular}

Source: Authors' computations. 
T A B LE 2 China-Côte d'Ivoire cooperation by domains, 1983 to 2013

\begin{tabular}{|llll|}
\hline Domain & No. of projects & No. of projects funded & Cost in USD \\
\hline Sport & 5 & 2 & $72,290.32$ \\
\hline Development & 5 & 3 & $1,029,831.24$ \\
\hline Health & 7 & 6 & $1,429,045.75$ \\
\hline Culture & 17 & 2 & $5,254,496.80$ \\
\hline Electoral process & 10 & 7 & $20,653,438.95$ \\
\hline Telecommunications & 6 & 5 & $835,545,430.36$ \\
\hline Defense & 6 & 3 & $30,755,684.06$ \\
\hline Agriculture & 21 & 12 & $400,075,097.48$ \\
\hline Trade-economic & 55 & 48 & $283,094,880.06$ \\
\hline Education & 14 & 4 & $349,708,895.29$ \\
\hline Infrastructures & 28 & 20 & $9,055,404,636.00$ \\
\hline Total & 174 & 112 & $10,983,023,726.31$ \\
\hline
\end{tabular}

Source: Authors' adaptation from Aurégan (2017).

\section{3 | THEORETICAL AND EMPIRICAL REVIEW}

\section{1 | Theoretical background}

Côte d'Ivoire transitioned different stages of economic development triggered by socio-political crises. Therefore, to situate this study the investment development path (IDP) model which is an extension of the ownership, location and internationalization (OLI) advantages theory (Dunning \& Narula, 1996; Dunning, 1981, 2001) is adopted. The IDP model links a country's FDI to its level of economic development. According to the model, the level of a country's FDI is related to different stages of its economic development (Gao, Liu, \& Zou, 2013). At the first stage, countries attract less FDI because the benefits of OLI are insignificant. The volume of inward FDI increases in the second stage because at this stage the size of the domestic market is sufficient and the improvement of consumer purchasing power attracts more FDI to the country. The third stage signals a reduction in inward FDI and the volume of outward FDI increases due to the development of national industry technology as national companies will seek to internationalize as a result of competition. In the fourth stage, as domestic firms expand internationally, outward FDI exceeds inward FDI. Finally, in the fifth stage, outward and inward FDI are balanced, which suggests that the domestic market has reached maturity (market saturation) and the global expansion of domestic firms. Gao et al. (2013) empirically tested the IDP theory and found that China outward FDI is driven by domestic economic development. In the same vein, Liu, Buck, and Shu (2005) surmise that for developing countries FDI is prompted by their state of economic development while according to You (2015) China FDI is not driven by the level of economic development in host countries. Likewise, Tuong Anh and Hung (2016) argue that Chinese investors are probably not associated with the economic growth of host countries.

\section{2 | Brief empirical review}

\subsection{1 | FDI and economic welfare}

The nature of causality between FDI and GDP per capita (proxy for economic welfare) is widely documented in the literature. However, the relationship between China FDI and economic welfare has not been specifically attended to. Findings are unanimous on the fact that economic growth improves economic welfare, while FDI stimulates economic growth of developing countries (Assadzadeh \& Pourqoly, 2013). Doku et al. (2017) use panel 
least squares to reveal a significant unidirectional causal relationship from FDI to GDP growth. Dunne and Masiyandima (2017) reveal that bilateral FDI fosters income convergence in the Southern African Development Community (SADC) region. However, Zhang, Alon, and Chen (2014) on 44 SSA countries find that neither FDI net inflows nor China FDI has a significant effect on economic growth in SSA. Using the Toda-Yamamoto Granger causality technique, Kaur, Yadav, and Gautam (2013) examine the causal relationship between GDP per capita (economic growth proxy) and FDI and find a bidirectional causality between FDI and economic growth. Jugurnath, Chuckun, and Fauzel (2016) use static and dynamic panel methods to examine the relationship of FDI and economic growth in 32 SSA countries and find that FDI does have a positive and significant relationship on economic growth. Also, on a study of North African economies, Soumare (2015) finds a bi-directional causality between real GDP per capita and real per capita FDI.

Equally, Claassen, Loots, and Bezuidenhout (2012) conclude that the relationship between Africa's GDP and China FDI is bi-directional. That is, African countries with higher GDP attract more volume of China FDI, while China FDI improves economic growth in African countries. Anyanwu and Yameogo (2015) find a U-shaped nonlinear relationship between FDI inflows into West Africa and economic development. Gathaiya, Kinyua, Machuki, and Keraro (2014) show that China FDI promotes economic growth in Kenya through human capital development, employment, and capital supply after testing the impact of China FDI on per capita GDP. Izuchukwu and Ofori (2014) reveal a bi-directional relationship between GDP and China FDI in Nigeria and conclude that FDI is a strong contributor to the country's GDP. Contrarily, Herzer, Klasen, and Nowak-Lehmann (2008) find no causality from FDI to growth. Similarly, Fofana, Xia, and Traore (2018) apply the pooled mean group estimation technique and panel-Granger causality models to analyze the dynamic relationship between China FDI, agriculture, and economic growth in West Africa. The findings confirm the absence of significant Granger causality between China FDI and economic growth. Likewise, for Tunisia, Belloumi (2014) finds no evidence of causality between FDI and economic growth by applying the Granger causality test using data for the period 1970-2008.

\subsection{2 | FDI and social welfare}

The literature is inundated with studies on FDI-social welfare nexus but only a few have investigated clear evidence on the direction of causality between China FDI and welfare outcomes in Africa. On sub-Saharan Africa (SSA), Fauzel, Seetanah, and Sannassee (2015) examine the nexus of FDI and welfare and find a unidirectional relationship between FDI and social welfare and also argue that FDI is an important ingredient for economic and social development because it helps to attain both economic welfare (higher growth) and social welfare (poverty reduction). Yogo (2017) shows that injecting foreign aid into education could hasten the attainment of the fourth sustainable development goal (SDG) for SSA. From Kaulihowa and Adjasi (2016), FDI can enhance welfare in African countries. Similarly, Lehnert, Benmamoun, and Zhao (2013) find that FDI has a positive effect on life expectancy, education, and standard of living of the host countries. Reiter and Steensma (2010) argue that FDI inflows are more strongly positively related to improvement in human development. According to Ross (2015), China FDI in African countries is driven by access to natural resources and factors related to infrastructure quality and the regulatory environment enforced by host governments. Also, Yanxia and Meibo (2015) investigate the effect of China FDI on poverty reduction and reveal that China FDI and poverty reduction exhibit an inverted U-shaped relationship which implies that when China FDI is insignificant in the host economy it has a negative effect on poverty reduction but as FDI increases, poverty level declines. In the same vein, Donou-adonsou and Lim (2018) examine the impact of China FDI on economic performance in Africa and conclude that China FDI plays a more important role in raising income per capita in Africa and also indicate that inward investment raises the standard of living in Africa's francophone countries. Furthermore, Magombeyi and Odhiambo (2018) investigate the relationship between FDI and poverty reduction in Botswana and found that FDI has a positive impact on poverty reduction in the short run but a negative impact in the long run. On Mauritius, Fauzel, Seetanah, and Sannassee (2016) investigate the relationship between FDI and poverty reduction (social welfare indicator) and conclude that FDI reduces poverty level or increases social welfare while asserting that a unidirectional causality is observed between FDI and poverty reduction. Lastly, using life expectancy at birth, Gökmenoğlu, Apinran, and Taşpınar (2018) confirm the significant impact of FDI on HDI in Nigeria. 
TABLE 3 Descriptive statistics and correlation analysis

\begin{tabular}{llllllll} 
Variables & Mean & Max & Min & Std Dev & HDI & PC & 1.00 \\
HDI & 0.44 & 0.492 & 0.4 & 0.03 & 0.94 & 1.00 \\
GDPPC & 1241.27 & 1731.30 & 836.33 & 258.25 & 0.72 & 0.62 \\
CFDI & 0.732 & 6.02 & -0.38 & 1.40 & 1.00 \\
\hline
\end{tabular}

Notes: CFDI, per capita China FDI; GDPPC, per capita real GDP, HDI, Human development index.

Source: Authors' computations.

\section{4 | DATA AND MODEL}

\section{1 | Data and sources}

This study uses quarterly data, due to weakness of annual observations, on Côte d'Ivoire from 2003Q1 to 2017Q4. The three variables used in this study are: human development index (HDI), the proxy for social welfare sourced from United Nations Development Program (2018); real per capita GDP (GDPPC), the measure of economic welfare obtained from the World Bank (2018) World Development Indicators; and China outward FDI to Côte d'Ivoire (CFDI) obtained from the Ministry of Commerce of China (2017). However, given that annual data is available for FDI, the quadratic match-average method is used to compute its quarterly variant. This method transforms the data from a low to high frequency data. The quadratic match-average approach has been adopted by many researchers (Tan et al., 2014; Normandin, 2006). The variables are transformed into natural logarithm for the following reasons: ease of interpretations, to smoothen the data, remove outliers, and to establish elasticity relationships. Descriptive statistics and correlation analysis of the variables are presented in Table 3.

Outcomes from Table 3 indicate a high deviation from the mean values of GDP per capita and that China FDI in Côte d'Ivoire is more volatile than HDI, which may be attributable to the conflicts and war in the country. HDI has the lowest standard deviation of 0.03 with a mean of 0.44 , and maximum and minimum values of 0.492 and 0.40 , respectively. The correlation matrix reveals a positive association among the variables.

\section{2 | Empirical model and estimation technique}

Analyses begin with estimations of two vector autoregressive (VAR) models. Following Gohou and Soumare (2012) and Fauzel et al. (2015), the two models are constructed to capture the FDI-welfare dynamics. For the first model shown as Equation (1), the dependent variable is the natural logarithm of human development index (lnHDI) which is the proxy for social welfare while for the second model of Equation (2), the dependent variable is the natural logarithm of real per capita GDP $(\ln G D P P C)$, the measure of economic welfare. The VAR model equation is specified as:

$$
\begin{gathered}
\ln H D I_{t}=\alpha+\sum_{i=1}^{k} \gamma_{i} \ln H D I_{t-i}+\sum_{j=1}^{k} \varphi_{j} \ln C F D I_{t-j}+\varepsilon_{1 t}, \\
\ln G D P P C_{t}=\beta+\sum_{i=1}^{k} \gamma_{i} \ln G D P P C_{t-i}+\sum_{j=1}^{k} \varphi_{j} \ln C F D I_{t-j}+\varepsilon_{2 t} .
\end{gathered}
$$

In line with the literature, the existence of causal relationships between China outward FDI and social and economic welfare is expected. For analysis on the causal relation, this study follows the methodology applied by Khemili and Belloumi (2018) who used the Toda-Yamamoto causality technique. This technique has an advantage over the conventional Granger causality technique because the maximum lag length is determined in the VAR system which does not change, hence produces reliable results (Leshoro, 2018).

The Toda-Yamamoto causality procedure is explained as follows: (a) obtain the order of maximum integration of the series under study $\left(d_{\max }\right)$ using stationarity tests, $(\mathrm{b})$ determine the lags or optimal shift of the VAR system ( $k$ ); (c) estimate a VAR in increased order level $p=k+d_{\text {max }}$; and (d) perform the causality test. Next, a variance decomposition analysis is performed to evaluate the strength of the causality between the variables. Basically, the 
variance decomposition aims to check the extent to which the predicted error variance for a given variable is explained by the innovations generated throughout each independent variable. The approach of Toda and Yamamoto's causality test involves the use of a modified Wald statistic from the non-causality hypothesis of the classical Granger (1969). After applying the VAR model, the causal relationship between the variables is examined using the Toda and Yamamoto causality test. To undertake the Toda-Yamamoto version of the Granger test for a VAR $(p)$ model, the following system of equations is estimated:

$$
\begin{gathered}
{\left[\begin{array}{c}
\ln H D I_{t} \\
\ln C F D I_{t}
\end{array}\right]=\left[\begin{array}{l}
\alpha_{1} \\
\alpha_{2}
\end{array}\right]+\sum_{i=1}^{k}\left[\begin{array}{l}
\beta_{1 i} \gamma_{1 i} \\
\beta_{2 i} \gamma_{2 i}
\end{array}\right]\left[\begin{array}{l}
\ln H D I_{t-i} \\
\ln C F D I_{t-i}
\end{array}\right]+\sum_{j=1}^{k+d m a x}\left[\begin{array}{l}
\beta_{1 j} \gamma_{1 j} \\
\beta_{2 j} \gamma_{2 j}
\end{array}\right]\left[\begin{array}{c}
\ln H D I_{t-j} \\
\ln C F D I_{t-j}
\end{array}\right]+\left[\begin{array}{l}
\varepsilon_{1 t} \\
\varepsilon_{2 t}
\end{array}\right],} \\
{\left[\begin{array}{c}
\ln G D P P C_{t} \\
\ln C F D I_{t}
\end{array}\right]=\left[\begin{array}{l}
\varnothing_{1} \\
\varnothing_{2}
\end{array}\right]+\sum_{i=1}^{k}\left[\begin{array}{l}
\vartheta_{1 i} \partial_{1 i} \\
\vartheta_{2 i} \partial_{2 i}
\end{array}\right]\left[\begin{array}{c}
\ln G D P P C_{t-i} \\
\ln C F D I_{t-i}
\end{array}\right]+\sum_{j=1}^{k+d \max }\left[\begin{array}{l}
\vartheta_{1 j} \partial_{1 j} \\
\vartheta_{2 j} \partial_{2 j}
\end{array}\right]\left[\begin{array}{c}
\ln G D P P C_{t-j} \\
\ln C F D I_{t-j}
\end{array}\right]+\left[\begin{array}{l}
\varphi_{1 t} \\
\varphi_{2 t}
\end{array}\right] .}
\end{gathered}
$$

where (3) relates to the causal relationship between CFDI and social welfare and (4) addresses the causal relationship between CFDI and economic welfare; ln denotes the natural logarithm, $k$ is the optimal lag length; $d_{\max }$ is the number of integration; $\alpha, \varnothing$ are intercepts; $\beta_{i}, \gamma_{i}, \partial_{i}, \vartheta_{i}$, are parameters to be estimated; $\varepsilon_{1 t}, \varphi_{1 t}$ are the error terms. To capture the causal relations between social welfare and FDI and between economic welfare and FDI, four equations are constructed from (3) and (4).

Social welfare and China FDI:

$$
\ln H D I_{t}=\alpha_{1}+\sum_{i=1}^{k} \beta_{1 i} \ln H D I_{t-i}+\sum_{j=1}^{k+d \max } \beta_{1 j} \ln H D I_{t-j}+\sum_{i=1}^{k} \gamma_{1 i} \ln C F D I_{t-i}+\sum_{j=1}^{k+d \max } \gamma_{1 j} \ln C F D I_{t-j}+\varepsilon_{1 t} .
$$

China FDI and social welfare:

$$
\ln C F D I_{t}=\alpha_{2}+\sum_{i=1}^{k} \gamma_{2 i} \ln C F D I_{t-i}+\sum_{j=1}^{k+d \max } \gamma_{2 j} \ln C F D I_{t-j}+\sum_{i=1}^{k} \beta_{2 i} \ln H D I_{t-i}+\sum_{j=1}^{k+d \max } \beta_{2 j} \ln H D I_{t-j}+\varepsilon_{2 t} .
$$

From (3), Equation (5) is the null hypothesis which states that China FDI does not Granger cause social welfare expressed as: $H_{0}: \gamma_{1 i}=0$, where $\gamma_{1 i}$ is the coefficient of the lagged values of $\ln C F D I$ variable in the social welfare equation against the alternate hypothesis $H_{1}: \gamma_{1 i} \neq 0$ : that is, China FDI Granger causes social welfare. Similarly, Equation (6) is the null hypothesis which states that social welfare does not Granger cause China FDI expressed as: $H_{0}: \beta_{2 i}=0$ against the alternative hypothesis $H_{1}: \beta_{2 i} \neq 0$ social welfare Granger causes China FDI. $\beta_{2 i}$ is the coefficient of the lagged values of $\ln H D I$ in China FDI equation.

Economic welfare and China FDI:

$$
\ln G D P P C_{t}=\varnothing_{1}+\sum_{i=1}^{k} \vartheta_{1 i} \ln G D P P C_{t-i}+\sum_{j=1}^{k+d \max } \vartheta_{1 j} \ln G D P P C_{t-j}+\sum_{i=1}^{k} \partial_{1 i} \ln C F D I_{t-i}+\sum_{j=1}^{k+d \max } \partial_{1 j} \ln C F D I_{t-j}+\varphi_{1 t} .
$$

China FDI and economic welfare:

$$
\ln C F D I_{t}=\varnothing_{2}+\sum_{i=1}^{k} \vartheta_{2 i} \ln G D P P C_{t-i}+\sum_{j=1}^{k+d m a x} \vartheta_{2 j} \ln G D P P C_{t-j}+\sum_{i=1}^{k} \partial_{2 i} \ln C F D I_{t-i}+\sum_{j=1}^{k+d \max } \partial_{2 j} \ln C F D I_{t-j}+\varphi_{2 t} .
$$

Ditto from (4), Equation (7) is the null hypothesis that China FDI does not Granger cause economic welfare expressed as: $H_{0}: \partial_{1 i}=0$ against the alternative hypothesis of the existence of causality. That is, $H_{1}: \partial_{1 i} \neq 0$. Similar analogy for (8) on the causal links between economic welfare and China FDI. 
TABLE 4 Unit root test results

\begin{tabular}{|c|c|c|c|c|c|c|c|}
\hline \multirow[b]{2}{*}{ Variables } & \multicolumn{3}{|c|}{ At level } & \multicolumn{3}{|c|}{ First difference } & \multirow[b]{2}{*}{ Outcome } \\
\hline & ADF & PP & KPSS & ADF & $\mathbf{P P}$ & KPSS & \\
\hline $\ln H D I$ & 0.788 & 0.237 & 0.960 & $-3.072^{* *}$ & $-4.615^{* *}$ & $0.074^{* * *}$ & $\mathrm{I}(1)$ \\
\hline $\ln P C$ & -0.943 & -1.192 & 0.897 & $-4.056^{* * *}$ & $-3.632^{* *}$ & $0.072^{* * *}$ & $\mathrm{I}(1)$ \\
\hline $\ln C F D I$ & -0.240 & -0.770 & 0.548 & $-3.735^{* * *}$ & $-5.053^{* *}$ & $0.110^{* * *}$ & $\mathrm{I}(1)$ \\
\hline & & \multicolumn{2}{|c|}{ ADF } & \multicolumn{3}{|c|}{ PP } & KPSS \\
\hline $1 \%$ level & & \multicolumn{2}{|c|}{-3.555} & \multicolumn{3}{|c|}{-3.546} & 0.739 \\
\hline $5 \%$ level & & \multicolumn{2}{|c|}{-2.916} & \multicolumn{3}{|c|}{-2.912} & 0.463 \\
\hline $10 \%$ level & & \multicolumn{2}{|c|}{-2.596} & \multicolumn{3}{|c|}{-2.594} & 0.347 \\
\hline
\end{tabular}

Notes: ADF, Augmented Dickey-Fuller; CFDI, per capita FDI; HDI, human development index; ln, natural logarithm; PC, per capita real GDP; PP, Phillips-Perron.

** Statistical significance at the $5 \%$ level.

*** Statistical significance at the $1 \%$ level.

Source: Authors' computations.

\section{5 | RESULTS AND DISCUSSION}

\section{$5.1 \quad$ Unit root test results}

To avoid obtaining spurious results, a stationary test is performed on all the variables. Hence, to validate the nonexistence of a unit root, the Augmented Dickey-Fuller (1979), Phillips and Perron (1988), and Kwiatkowski, Phillips, Schmidt, and Shin (1992) unit root tests are applied. Equation (9) presents the equation for the unit root test:

$$
\Delta F_{t}=\beta_{\circ}+\delta_{\circ} T+\delta_{1} F_{t-1}+\sum_{i=1}^{m} \beta_{1} \Delta F_{t-1}+\mu_{t},
$$

where, $F$ is the variable to be tested; $\Delta$ is the first difference operator; $T$ denotes the linear trend; $t$ represents time; and $m$ is the lag length while $\mu_{t}$ represents the white noise residuals. The null hypothesis of the augmented Dickey-Fuller (ADF) and Phillips-Perron (PP) tests is that the series is non-stationary while the null hypothesis of the KwiatkowskiPhillips-Schmidt-Shin (KPSS) test is that the variable is stationary. The ADF unit root test has weak power in rejecting the null hypothesis of no stationarity which is why the KPSS unit root test is elaborated to bring perfection to the ADF unit root test (Tarawalie, Sissoho, Conte, \& Ahortor, 2012). The results of the unit root tests, which indicate that all the variables are stationary after first difference, are shown in Table 4.

\section{2 | Optimal lags selection}

The optimal lag length is important to identify the true dynamics of the model. To determine the optimal lag length of the VAR system, the sequential modified LR test statistic (LR), final prediction error (FPE), Akaike information criterion (AIC), Schwarz information criterion (SC), and Hannan-Quinn information criterion (HQ) lag selection criteria are used. For analysis, the AIC is retained to determine the optimal lag length of VAR system and indicates that the lag order of VAR $(k)$ is 9 for both models. It should be noted that lag " 11 " for model 1 and lag " 10 " for model 2 are retained after estimations as they offered optimal and efficient VAR model compared to the lag " 9 " for both models. 
TAB LE 5 Diagnostic tests results

\begin{tabular}{llll} 
& \multicolumn{2}{l}{ Stat./p-values } & \\
\cline { 2 - 4 } Specification & Model 1 & Model 2 & Conclusion \\
Breusch-Godfrey (autocorrelation) & $2.283 / .6841$ & $1.235 / .872$ & No higher-order autocorrelation \\
Breusch-Pagan (heteroscedasticity) & $99.91 / .984$ & $122.33 / .424$ & No heteroscedasticity \\
\hline Jarque-Bera (normality) & $49.687 / .000$ & $29.242 / .000$ & Normality rejected \\
Stability & Roots lie within unit circle & Models are stable
\end{tabular}

Source: Authors' computations.

\section{3 | VAR diagnostics}

The results from the VAR diagnostics (due to space, the results of the underlying VAR results are made available upon request) shown in Table 5 indicate that the null hypotheses of no higher-order autocorrelation, heteroscedasticity and stability cannot be rejected at the 5\% level but the Jarque-Bera test for normality is rejected at the $1 \%$ level for both models. However, the lack of normality does not mean that the model is invalid (Geamănu, 2014) and does not negatively affect the outcomes of our estimations (Gonzalo, 1994). Figure 2, shows that the roots of the VAR systems for both models lie within the unit circle.

\section{4 | Causality test results}

From Table 6, the value of the $\chi^{2}$ statistic (modified Wald) for Equations (1), (3), and (5) is 34.41 with a corresponding $p$-value of .0003 indicating a statistical significance at the $1 \%$ level, which evidences a unidirectional causality from China FDI to social welfare. These results imply that the injection of China investment enhances the human development index and that an improvement of this index does not really encourage China's urge to invest in Côte d'Ivoire. The inferences from the CFDIHDI relation is not far-fetched. Why? This is because China FDI influences social welfare in Côte d'Ivoire as a result of investments in sectors that have a direct bearing on the people's welfare. For instance, China FDI stimulates government spending on vital sectors in health, education, agriculture, infrastructures, and ICT, which are the core components of the human development index which, on aggregate, improve social welfare in Côte d'Ivoire. This result is consistent with those

Inverse Roots of AR Characteristic Polynomial

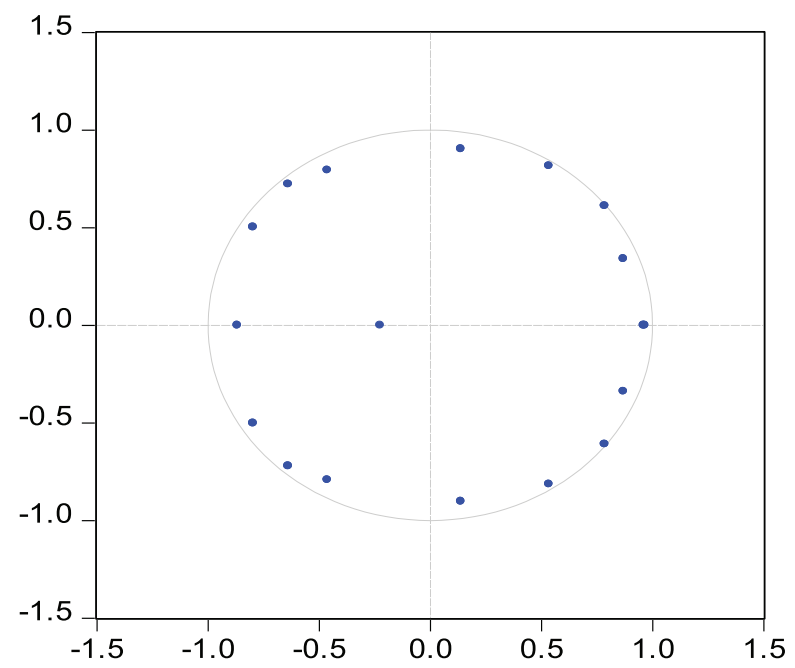

Inverse Roots of AR Characteristic Polynomial

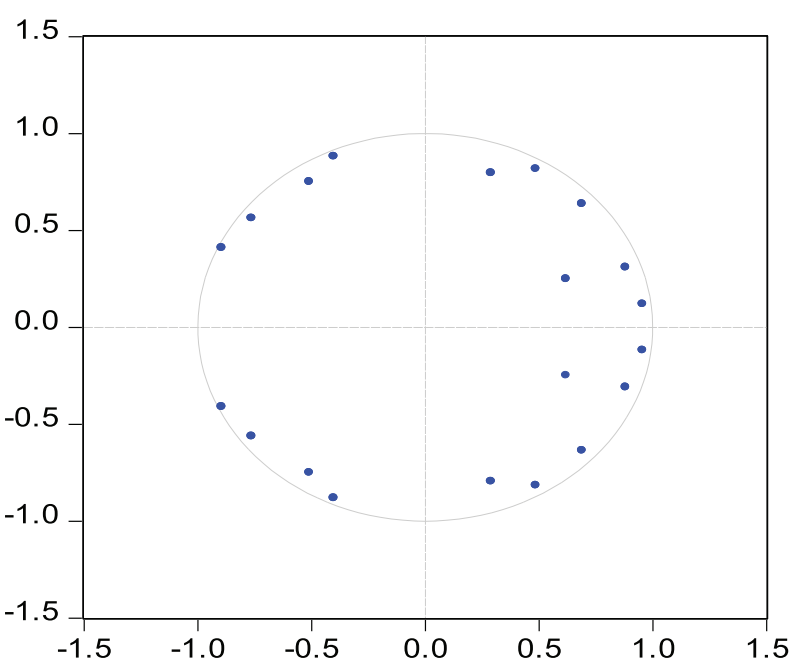

FIG URE 2 Inverse roots of AR characteristic polynomialSource: Authors' computations [Color figure can be viewed at wileyonlinelibrary.com] 
TAB LE 6 Granger non-causality test results

\begin{tabular}{|c|c|c|c|}
\hline \multirow[b]{2}{*}{ Null hypotheses } & \multicolumn{2}{|l|}{ Model 1} & \multirow[b]{2}{*}{ Direction of causality } \\
\hline & $p$-value & Coefficient (Modified Wald) & \\
\hline$H_{0}: \gamma_{11}=\gamma_{12}=0$ & $.0003^{* * *}$ & 34.406 & $\ln C F D I$ to $\ln H D I$ (unidirectional) \\
\hline \multirow[t]{2}{*}{$H_{0}: \beta_{21}=\beta_{22}=0$} & .5209 & 10.105 & \\
\hline & \multicolumn{2}{|l|}{ Model 2} & \\
\hline$H_{0}: \partial_{11}=\partial_{12}=0$ & .164 & 14.202 & No causality \\
\hline$H_{0}: \vartheta_{21}=\vartheta_{22}=0$ & .828 & 5.838 & \\
\hline
\end{tabular}

Note: Null hypotheses are as expressed in Equations (5), (6), (7), and (8).

*** Significant levels at $1 \%$ level.

Source: Authors' computations.

obtained by Claassen et al. (2012) and Liu et al. (2017) who argue that infrastructural development in Africa does not attract China investment, but rather it is the lack of infrastructure that motivates China investment. Lehnert et al. (2013) supported similar outcomes that FDI cause social welfare measured by education, health, and standard of living on the host country.

To the contrary, no causal relationship exists between China FDI and economic welfare. In other words, the study asserts that economic welfare is not influenced by China FDI in Côte d'Ivoire and vice versa. The reasons of this outcome are also not far-fetched. First, China FDI as a share of GDP over the study period is rather small and constitutes an insignificant share of total investment inflow in the country. In other words, China FDI might simply be too marginal to have a serious impact on economic growth (welfare economics). Second, China FDI into Cote d'Ivoire is directed towards infrastructural development which has no direct impact on the economy. It is recognized that Cote d'Ivoire has an agrarian economy (Ducroquet, Tillie, Louhichi, \& Gomez-Y-Paloma, 2017; FAO, 2009) and China investment in agriculture is marginalized. In fact, only 12 out of 21 agricultural projects are unfunded compared to infrastructures (see Table 2). Third, this outcome may support Furuoka (2017) that China's provision of foreign aid is mostly driven by its self-interest.

\section{6 | CONCLUSION AND POLICY RECOMMENDATIONS}

This paper employs an innovative methodology of Toda and Yamamoto (1995) to test the direction of causality between China FDI and welfare in Côte d'Ivoire using quarterly data for Côte d'Ivoire from 2003Q1 to 2017Q4. The empirical findings show that a unidirectional causality relationship exists between social welfare and China FDI but none between China FDI and economic welfare. These results have some important policy recommendations. Policies that will further stimulate China FDI must be carefully crafted to attract investment to the most productive sectors of the economy in order to improve both social and economic welfare. The lack of causation from China FDI to economic welfare is attributable to the low investment of China FDI in agriculture, which is the bedrock of the country's economy. Therefore, there is need to boost agro-sector development to make it attractive for foreign investors and not just China. In addition, China FDI expansionary policy might bring higher social welfare (HDI). So, the Ivorian authorities would also benefit from taking adequate measures aimed at strengthening the quality of institutions and good governance in order to create confidence in China investors. The basic socio-economic infrastructure, which is essential and a prerequisite for any development strategy, must be strengthened in Côte d'Ivoire. The government must strengthen a win-win relation with China to accelerate investment in agriculture, health, and education to achieve the objective of improving the welfare of the populations of Côte d'Ivoire. For further studies and given availability of data, the relationship between China FDI and institutional quality in Côte d'Ivoire may be taken up.

\section{ORCID}




\section{REFERENCES}

Adeleye, N., Osabuohien, E., \& Bowale, E. (2017). The role of institutions in the finance-inequality nexus in Sub-Saharan Africa. Journal of Contextual Economics, 137, 173-192.

Anyanwu, J. C., \& Yameogo, N. D. (2015). What drives foreign direct investments into West Africa? An empirical investigation. African Development Review, 27(3), 199-215.

Assadzadeh, A., \& Pourqoly, J. (2013). The relationship between foreign direct investment, institutional quality and poverty: Case of MENA countries. Journal of Economics, Business and Management, 12, 161-165.

Aurégan, X. (2017). Les investissements publics chinois dans les filières agricoles ivoiriennes. Cahiers Agricultures, 26(15003), 1-9.

Belloumi, M. (2014). The relationship between trade, FDI and economic growth in Tunisia: An application of the autoregressive distributed lag model. Economic Systems, 38, 1-19.

Claassen, C., Loots, E., \& Bezuidenhout, H. (2012). Chinese foreign direct investment in Africa: Making sense of a new economic reality. African Journal of Business Management, 6,(47), 11583-11597.

Dickey, D. A., \& Fuller, W. A. (1979). Distribution of the estimation for autoregressive time series with unit root. Econometrica, 49, 1057-1072.

Doku, I., Akuma, J., \& Owusu-Afriyie, J. (2017). Effect of Chinese foreign direct investment on economic growth in Africa. Journal of Chinese Economic and Foreign Trade Studies, 10(2), 162-171.

Donou-adonsou, F., \& Lim, S. (2018). On the importance of Chinese investment in Africa. Review of Development Finance, 8(1), 63-73.

Ducroquet, H., Tillie, P., Louhichi, K., \& Gomez-Y-Paloma, S. (2017). L' agriculture de la Côte d' Ivoire à la loupe.

Dunne, J. P., \& Masiyandima, N. (2017). Bilateral FDI from South Africa and income convergence in SADC. African Development Review, 29(3), 403-415.

Dunning, J. H. (2001). The eclectic (OLI) paradigm of international production: Past, present and future. International Journal of the Economics of Business, 8(2), 173-191.

Dunning, JohnH., \& Narula, R. (1996). The investment development path revisited - Some emerging issues. In J. Dunning \& J. Narula (Eds.), Foreign direct investment and governments (pp. 1-41). London: Routledge.

FAO. (2009). Rapport national sur l'état des ressources phytogénétiques pour l'alimentation et l'agriculture.

Fauzel, S., Seetanah, B., \& Sannassee, R. (2015). Foreign direct investment and welfare nexus in sub Saharan Africa. The Journal of Developing Areas, 49(4), 271-283.

Fauzel, S., Seetanah, B., \& Sannassee, R. V. (2016). A dynamic investigation of foreign direct investment and poverty reduction in Mauritius. Theoretical Economics Letters, 06(April), 289-303.

Fofana, K. H., Xia, E., \& Traore, M. B. (2018). Dynamic relationship between Chinese FDI, agricultural and economic growth in West African: An application of the pool mean group model. Journal of Physics: Conference Series, 1060(012066), 1-12.

Furuoka, F. (2017). Determinants of China's and Japan's foreign aid allocations in Africa. African Development Review, 29(B3), 376-388.

Gamassa, P. K. P., \& Chen, Y. (2017). The impact of China one belt one road on Abidjan port development based on gravity model. International Journal of Trade, Economics and Finance, 8(3), 141-148.

Gao, L., Liu, X., \& Zou, H. (2013). The role of human mobility in promoting Chinese outward FDI: A neglected factor? International Business Review, 22(2), 437-449.

Gathaiya, R. N., Kinyua, J., Machuki, P., \& Keraro, V. (2014). The impact of foreign direct investments by chinese Companies in Kenya. International Journal of Management \& BusIness StudIes, 4(1), 9-17.

Geamănu, M. (2014). VAR analysis on foreign direct investment in Romania. Theoretical and Applied Economics, 21(4), 39-52.

Gohou, G., \& Soumare, I. (2012). Does foreign direct investment reduce poverty in Africa and are there regional differences? World Development, 40(1), 75-95.

Gökmenoğlu, K. K., Apinran, M. O., \& Taşpınar, N. (2018). Impact of foreign direct investment on human development index in Nigeria. Business \& Economics Research Journal, 9(1), 1-13.

Gonzalo, J. (1994). Five alternative methods of estimating long-run equilibrium relationships. Journal of Econometrics, 60(1-2), 203-233.

Granger, C. W. J. (1969). Investigating causal relations by econometric models and cross-spectral methods. Econometrica, 37(3), 424-438.

Herzer, D., Klasen, S., \& Nowak-Lehmann, F. (2008). In search of FDI-led growth in developing countries: The way forward. Economic Modelling, 25(5), 793-810.

Izuchukwu, O. -O., \& Ofori, D. (2014). Why south-south FDI is booming: Case study of China FDI in Nigeria. Asian Economic and Financial Review, 4(3), 361-376.

Jugurnath, B., Chuckun, N., \& Fauzel, S. (2016). Foreign direct investment \& economic growth in sub-Saharan Africa: An empirical study. Theoretical Economics Letters, 6(August), 798-807.

Kaulihowa, T., \& Adjasi, C. (2016). FDI and welfare dynamics in Africa. Thunderbird International Business Review, 14(4), 1984-1990.

Kaur, M., Yadav, S. S., \& Gautam, V. (2013). A bivariate causality link between foreign direct investment and economic growth evidence from India. Journal of International Trade Law and Policy, 12(1), 68-79.

Kwiatkowski, D., Phillips, P. C. B., Schmidt, P., \& Shin, Y. (1992). Testing the null hypothesis of stationarity against the alternative of a unit root. Journal of Econometrics, 54((1-3)), 159-178.

Khemili, H., \& Belloumi, M. (2018). Cointegration relationship between growth, inequality and poverty in Tunisia. International Journal of Applied Economics, Finance and Accounting, 2(1), 8-18. 
Lehnert, K., Benmamoun, M., \& Zhao, H. (2013). FDI inflow and human development: Analysis of FDI’s impact on host countries' social welfare and infrastructure. Thunderbird International Business Review, 55(3), 285-298.

Leshoro, T. L. (2018). Trade unions' inflation expectations and the second-round effect in South Africa. PSL Quarterly Review, Economia civile, 71(284), 85-94.

Liu, H. Y., Tang, Y. K., Chen, X. L., Poznanska, J., Liu, H. Y., Tang, Y. K., \& Chen, X. L. (2017). The determinants of Chinese outward FDI in countries along “One Belt One Road.”. Emerging Markets Finance and Trade, 53(6), 1374-1387.

Liu, X., Buck, T., \& Shu, C. (2005). Chinese economic development, the next stage: Outward FDI? International Business Review, 14(1), 97-115.

Magombeyi, M. T., \& Odhiambo, N. M. (2018). FDI inflows and poverty reduction in Botswana: An empirical investigation. Cogent Economics and Finance, V6(1), 1-15.

Megbowon, E., Mlambo, C., \& Adekunle, B. (2019). Impact of china's outward fdi on sub-saharan africa's industrialization: Evidence from 26 countries. Cogent Economics \& Finance, 7(1), 1681054.

Mofcom. (2015). 2015 Statistical Bulletin of China’s Outward Foreign Direct Investment. Retrieved from: http://cdi.cnki.net/Titles/SingleNJ? NJCode $=$ N2018110033

Normandin, Michel (2006). Fiscal policies, external deficits and budget deficits. In Leo N. Bartolotti (Ed.), Inflation, fiscal policy and central banks (pp. 1-29). Nova Science Publishers.

Phillips, P. C., \& Perron, P. (1988). Testing for a unit root in time series regression. Biometrika, 75, 335-346.

Reiter, S. L., \& Steensma, H. K. (2010). Human development and foreign direct investment in developing countries: The influence of FDI policy and corruption. World Development, 38(12), 1678-1691.

Ross, A. G. (2015). An empirical analysis of Chinese outward foreign direct investment in Africa. Journal of Chinese Economic and Foreign Trade Studies, 8(1), 4-19.

Seka, P. R., \& Kouakou, C. K. (2008). Relations économiques entre la Chine et l'Afrique: Le cas de la Côte d'Ivoire. African Economic Research Consortium (AERC), 1-26.

Soumare, I. (2015). Does FDI improve economic development in North African countries? Applied Economics, 47(51), 5510-5533.

Tan, K. G., Merdikawati, N., Amri, M., Tan, K. Y., Eko Wuryanto, L., \& Juoro, U. (2014). Geweke Analysis on causal Linkages for East Java, East Kalimantan, North Maluku and East Nusa Tenggara. In A. M. Tan Khee Giap, Merdikawati Nurina (Eds.), 2014 provincial and inaugural regional competitiveness analysis: Safeguarding Indonesia's growth momentum (pp. 131-161).

Tarawalie, A, B., Sissoho, M., Conte, M., \& Ahortor, C., R. (2012). Real Exchange Rate Volatility and Export Performance in the West African Monetary Zone (WAMZ), A Paper Prepared for the Third Annual Conference on Regional Integration in Africa, Dakar, Senegal.

Toda, H. Y., \& Yamamoto, T. (1995). Statistical inference in vector autoregressions with possibly integrated processes. Journal of Econometrics, 66((1-2)), 225-250.

Tuong Anh, N. T., \& Hung, D. Q. (2016).Chinese outward foreign direct investment: Is ASEAN a new destination?Working Paper No. 06, World Trade Institute of the University of Bern, Switzerland.

UNDP. (2016). Human development report: Human development for everyone. New York, USA.

UNDP. (2018). Human development indices and indicators. Statistical update. New York, USA.

World Bank. (2017). Situation économique en Côte d'Ivoire. 4ème édition, Janvier 2017, Groupe de la Banque Mondiale. New York and Geneva: United Nations.

World Bank. (2018) The World Bank annual report 2018. New York and Geneva: United Nations.

Xinhua News Agency.,(2018).China, Cote d'Ivoire agree to promote bilateral ties to higher level, http://www.xinhuanet.com/english/201808/30/c_137431164_2.htm, 2018-11-15

Yanxia, Z., \& Meibo, H. (2015). Poverty reduction effects of Chinese FDI to Africa: A study based on the methodology of dynamic panel data GMM. World Economy Studies, 11, 90-98.

Yogo, T. U. (2017). Assessing the effectiveness of foreign aid in the education sector in Africa: The case of primary education. African Development Review, 29(3), 389-402.

You, K. (2015). What drives China's outward FDI? A regional analysis? Bank of Finland, Institute for Economies in Transition. BOFIT Discussion Papers 16/2015.

Zhang, J., Alon, I., \& Chen, Y. (2014). Does Chinese investment affect sub-Saharan African growth? International Journal of Emerging Markets, 9(2), 257-275.

How to cite this article: Allou EJ, Adeleye BN, Cheng J, Abdul R. Is there a nexus between China outward foreign direct investment and welfare in Côte d'Ivoire? Empirical evidence from the Toda-Yamamoto procedure. Afr Dev Rev. 2020;1-12. https://doi.org/10.1111/1467-8268.12456 